\title{
A Traveling Ethnography of Voice in Qualitative Research
}

Virginie Magnat, Ph.D.

Associate Professor

Faculty of Creative and Critical Studies

The University of British Columbia, Okanagan Campus

CCS 368, 1148 Research Rd.

Kelowna, BC V1V 1V7 Canada

Author Biography: Virginie Magnat is Associate Professor in the Faculty of Creative and Critical Studies at the University of British Columbia, Canada. Her monograph Grotowski, Women, and Contemporary Performance: Meetings with Remarkable Women (Routledge 2014) and its companion documentary film series (Routledge Performance Archive) are based on four years of embodied research and multi-sited fieldwork funded by the Social Sciences and Humanities Research Council of Canada. Her current research, also funded by SSHRC, explores the performative power of vocality as a vital source of human creativity and embodied knowledge grounded in process, practice, and place, as well as a form of social and political agency, as well as a form of social and political agency.

Acknowledgments/Credits: The author thanks Magdalena Kazubowski-Houston for her dedication, passion, and collaborative spirit; two anonymous reviewers for their constructive critical insights; Robert Ornellas for his careful editorial assistance; and Konstantinos Thomaidis for his guest appearance in the second part of this article.

Funding: This paper is part of a larger project funded by an Insight Grant and a Connection Grant from the Social Sciences and Humanities Research Council of Canada. 


\section{A Traveling Ethnography of Voice in Qualitative Research}

Abstract: This interdisciplinary exploration of voice seeks to open a space for the nondiscursive performative power of vocality in qualitative research. In the first part, I focus on anthropology and ethnographic practice to identify the ways in which "voice" gets muted when transformed by scriptocentrism (see Dwight Conquergood) into a conceptual abstraction or a metaphor. Given anthropology's colonial legacy and the implication of ethnographers in what Anthony Kwame Harrison defines as the project of literatizing non-literate societies, I argue that the potentially scriptocentric dimension of ethnographic practice must be taken seriously in light of the travels of ethnography across disciplines and its increasingly widespread usage within qualitative inquiry. In the second part, I foreground cultural theorist Adriana Cavarero's critique of the devocalization of logos in Western philosophy and its analysis by interdisciplinary voice studies scholar Konstantinos Thomaidis, who investigates the systematic exclusion, marginalization and silencing of voice through Eurocentric constructions of logos as reason and as language. By means of an imaginary visit to ancient Greece, I scrutinize Plato's anxiety vis-avis performance through an ethnographic encounter with the Ion, a dialogue between Socrates and a well-known champion of rhapsodic contests. On the basis of this performative ethnographic fieldwork, I suggest that conducting qualitative research on the significance and relevance of vocality today requires listening to, engaging with, and learning from the voices of ancient and contemporary oral cultural practitioners.

Keywords: Vocality, embodiment, performance, ethnography, scriptocentrism, devocalization, orality, agency, dialogism, song 


\section{A Traveling Ethnography of Voice in Qualitative Research}

\section{Part I: "Voice" in the Anthropological Ethnographic Project}

In his chapter on ethnography for the Oxford Handbook of Qualitative Research, Anthony Kwame Harrison (2014) states:

Etymologically, ethnography combines ethno, meaning 'culture (or race)' and graphy, meaning to write, record, and describe. Thus ethnography, which Barbara Tedlock (2000) refers to as an 'inscription practice' (p. 455), can be thought of as the process and product of writing, recording, and describing culture (p. 225)

Harrison traces the origins of this practice to the prominent and controversial figure of Malinowski and foregrounds "the colonial legacy of the ethnographic project" (p. 226), specifying that in 1909 the principals of Oxford, Cambridge and the London School of Economics determined that the term ethnography was to be employed to refer to the "descriptive accounts of non-literate peoples (Radcliffe-Brown 1952, p. 276)” (p. 231). Ethnography was therefore conceived as a method designed to make the cultural practices of the Other legible to the West by translating orality and embodiment into scholarly writing whose truth value was legitimized through publication. This privileging of literacy and print culture can be related to Dwight Conquergood's (2013) notion of scriptocentrism based on Raymond Williams's (1958/1983) critique of the contempt for embodied and practical activities "always latent in the highly literate," considered by Williams as "a mark of the observer's limits, not those of the activities themselves," as exemplified by the assumption that "farm labourers and village craftsmen were once uneducated, merely because they could not read (Williams, 309)" (Conquergood. 2013b, p. 34). Conquergood infers that "scholarship is so skewed toward texts 
that even when researchers do attend to extralinguistic human action and embodied events they construe them as texts to be read," an attitude he considers to be a hallmark of Western imperialism (2013b, p. 34). In "Re-thinking Ethnography: Towards a Critical Cultural Politics," Conquergood further remarks:

I do not imagine life in a university without books, nor do I have any wish to stop writing myself. But I do want to keep thinking of what gets lost and muted in texts. Following Turner and others, I want to keep opening spaces for nondiscursive forms, and encouraging research and writing practices that are performance-sensitive. (Conquergood, 2013c, p. 98) Accordingly, I seek to open in this article a space for the exploration of the non-discursive performative power of vocality, which first requires identifying the ways in which voice gets muted when reduced by scriptocentrism to a conceptual abstraction or a metaphor within qualitative research.

Since its Malinowskian beginnings, the discipline of anthropology has undergone profound epistemological and methodological changes, provoking intense internal tensions that reached their apex during the 1980s. In Turning Points in Qualitative Research, Norman K. Denzin and Yvonna S. Lincoln (2003) link these tensions to the triple crises of authority, representation, and praxis" that brought about a deep questioning of the nature and function of the social sciences, so that "the traditional criteria for evaluating qualitative work were challenged, as it was understood that researchers created reality through their representational, textual, and interpretive practices. The two crises of authority and representation shaped the third, asking how praxis or action was defined under a new interpretive regime. (p. 3) 
Harrison points out that the male academics who were at the forefront of the postmodern turn in anthropology during this period were credited for breaking new ground when calling into question notions of scientific objectivity and impartiality, yet they failed to acknowledge previous and on-going critiques by their feminist and Indigenous counterparts indicting Western male anthropologists who had "historically enjoyed the privilege of claiming objectivity and, quite notably, had their claims accepted by their audiences (Alsup, 2004)" (Harrison, 2014, p. 242). He stresses that postmodern male anthropologists have thus been compared by feminist scholars to "European explorers" (Mascia-Lees et al., 1989, in Harrison, 2014, p. 242) claiming to have discovered an allegedly uncharted territory as if somehow still driven by the colonial impulse underlying an early conception of ethnography that they so adamantly disavowed. Moreover, whereas the postmodern turn marked by the publication of Writing Culture (Clifford \& Marcus, 1986) placed the ethno of ethnography and its fraught relationship to culture and race under scrutiny, the emphasis on graphy remained central to postmodern anthropology, albeit in a more self-reflexive and performative fashion. Harrison hence remarks that the "new ethnography" that emerged from this postmodern movement has been characterized by an "emphasis on the rhetorical processes involved with ethnographic production and, ultimately, the view of ethnographies as writerly projects" (p. 243). The potentially scriptocentric dimension of such projects must be taken seriously in light of the travels of ethnography across a vast continuum of research areas and its increasingly widespread usage within qualitative inquiry by scholars engaged in the description, analysis, and interpretation of lived experience, cultural practices, and social relations.

Indeed, Harrison (2014) observes that "during the late twentieth century and now into the twenty-first, ethnography moved from the confined ranges of anthropology and sociology to a 
tremendous number of disciplines and fields" (p. 225). He emphasizes the "expansive and continually expanding" spectrum of ethnographic practices, including some of the more recent approaches that "cross into visual and sensory studies (Pink, 2006, 2009), the arts (Leavy, 2009; Schneider \& Wright, 2010), action-oriented research (Kemmis \& McTaggart, 2000), autoethnography (Ellis, 2004; S. H. Jones, 2008), and collaborative ethnography (Lassiter, 2005)" (p. 225). He then warns against a dilution of the specificity of ethnographic practice which he argues "involves more than just going somewhere to conduct research on or within a community," suggesting that the integrity of this practice is premised upon "a certain frame of mind" that he associates with a "historically aware sensibility that is very much its own," and envisioning ethnography as a sophisticated methodology that "involves degrees of impetus, intention, and conviction that are different from simply having a participant-observatory perspective and standpoint" (pp. 225-226). Yet beyond these disciplinary-specific considerations that continue to fuel vigorous debates among anthropologists, as reflected by George E. Marcus and Paul Rabinow's dialogue in Designs for An Anthropology of the Contemporary (2008), the chapter authored by Harrison most saliently foregrounds the enduring continuity of the writerly dimension of ethnography that connects the literary turn in postmodern anthropology back to Malinowski's pioneering work. For, as Harrison points out, Clifford himself invokes the "founding father" of ethnography on the first page of Writing Culture when "arguing the partial and constructed nature of truth claims, and advancing the artistic dimensions of ethnography as a project profoundly situated between systems of meaning making” (p. 243). Relying on the lineage he provocatively establishes between Malinowski's and Clifford's perspectives, Harrison seeks to reclaim a form of methodological consistency within the evolution of ethnographic practice. He argues that this evolution has been "gradual, reflective, and historically mediated" 
(p. 226), and that the uniqueness of ethnography resides in a capacity to operate "in an adverbial mode" both as research and as a representational practice that contextualize the social dynamics of fieldwork by reconstructing experience "through the process of writing first field notes (Emerson et al., 1995) and later ethnographic monographs" (p. 243). Harrison would therefore legitimize the persistent dominance of graphy by positing the latter as a valuable primary property of ethnography's epistemological and methodological DNA.

However, the colonial legacy of the ethnographic project resurfaces in a loopback effect at the end of the chapter when Harrison (2014) acknowledges an arresting paradox: "Ethnography's foundations are in writing culture, yet historically ethnographers are deeply implicated in the project of literatizing non-literate societies," which compels him to ask two crucial questions that remain open-ended: "What non-literal forms of ethnographic representation might a contemporary, critical, and historically informed ethnographic project take? How can we move beyond writing culture?" (p. 245). I would contend that these questions are particularly relevant to the interdisciplinary exploration of vocality within qualitative research. Performance studies scholar Diana Taylor $(2003,2008,2016)$ considers orally transmitted cultural practices to constitute a repertoire of embodied memory expressed through story, song, music, and dance. The vitality and resilience of this repertoire hinges upon a learning in and through the body that enables cultural practitioners to create, preserve, and transmit oral forms of knowledge. Crosscultural analyses of orally transmitted vocal music traditions corroborate the importance of embodied memory since "prescribed series of sound or sound relations [are] specified by an exemplar (such as remembered performance) rather than in written notation" (Tenzer and Roeder, 2011, p.11). Consequently, subtleties of interpretation hinging upon melismatic techniques, ornamentation, and regional variations are lost when this oral repertoire is transposed 
into writing through standard Western notation (Magnat, 2017). Similarly, when oral language is "literatized" into discursive language, vocalization's oral, sonic, and vibratory qualities, sensorial and affective properties, experiential cognitive potentialities, and vital relational dimension are lost in translation, and the decontextualized "voice" becomes a conceptual abstraction or a metaphor.

In “Anthropology and Voice,” Amanda Weidman (2014) points to the disjunction between anthropology's concern with agency, subjectivity, representation, and power - the metaphorical sense of "having a voice" - and the more sonically and linguistically focused study of actual voices and vocal practices, usually undertaken within the subfields of ethnomusicology and linguistic anthropology. (p. 38)

Weidman's extensive literature review exposes anthropology's “methodological conceit about the authenticity of the voice, inherited from Western ideologies" (p. 46) that associate the voice of the autonomous, rational, speaking subject with self-presence and interiority, as well as with individual agency, will, and authority. Moreover, this enduring conception of subjectivity tends to privilege linguistic-centered discourses on voice positing that "the sonic and material aspects of the voice are separable from and subordinate to its referential content and message" (p. 39). This is clearly exemplified by Ferdinand de Saussure's (1921/1988) distinction between langue and parole, the latter being excluded from the study of language as an abstract system of signs because it is rooted in the lived experience of particular individuals situated within an historically and culturally specific context. Psychosociologist Bernadette Bailleux (2001) questions this privileging of langue over parole and offers a psychophysical approach to vocality based on the relationship she establishes between voice and embodiment. She argues that an individual's "vocal style" is constituted by all her experiences throughout the course of her life, as well as by 
the various ways in which she might consciously or unconsciously identify with some of these experiences, including class-based identifications that manifest themselves vocally through accents. Gender also constitutes a major factor in the reproduction of normative vocal behavior, so that speaking with a high-pitched voice, for example, becomes a sonic marker of femininity associated with being a woman (Karpf, 2006; Sidtis and Kreiman, 2011), a form of conditioning which may be perceived as the vocal equivalent to the type of physical behavior defined as habitus by Pierre Bourdieu (1980). Most importantly for this discussion, Bailleux includes within the category of vocal style the kind of vocal work that performers undertake to train their voices for the purpose of artistic practice (pp. 203-06, 210), which can be perceived as a form of deconditioning when this training interrupts and reconfigures the normative vocal practices through which socially constructed identities become naturalized.

Weidman's literature review foregrounds a range of "denaturalizing perspectives on voice [that have] emerged from the fields of linguistic anthropology, musicology, ethnomusicology, and media and technology studies" (p. 39), whose critique of the Western metaphysics of voice seeks to offer counter-discourses that historicize and theorize the "always-constructed relationship between voices and bodies in different kinds of contexts" (pp. 41-12). She suggests that Mikhail Bakhtin's (1981) notion of dialogism constitutes one of the most effective theoretical destabilizations of dominant Western conceptions of a unitary autonomous subject, for he envisions the voice as "collectively produced [through] the play of different and competing voices within any utterance, which he termed heteroglossia” (p. 42). She provides the example of Amanda Minks (2013), who builds on this dialogical perspective in her ethnography of the vocal playfulness of Indigenous children living in a multi-ethnic and multilingual community on the Atlantic Coast of Nicaragua and infers that "we come to know ourselves and 
position ourselves in society by echoing, transforming, or silencing the voices of others (p. 4)" (p. 43). Weidman goes on to discuss the concept of voicing, which emphasizes "the strategic and politically charged nature of the way voices are constructed in both formal and everyday performances" (p. 42). She remarks that although voicing is predominantly employed in the study of spoken discourse, this concept "may also introduce questions of authorship and agency in relation to sung expression," (p. 43) leading her to ask whether singing might provide a performative agency that would otherwise be unavailable to speakers, particularly in instances where freedom of speech is undermined by censorship.

Alternatively, the performativity of voicing can be deployed to generate, consolidate, and naturalize normative models of social and cultural identity enforced through the institutionalization of oppressive and exclusive practices that sustain and perpetuate dominant structures of power. Weidman relates such practices to Bourdieu's (2001) investigation of the “symbolic power of language," J. L. Austin's (1962) conceptualization of performative utterances as "doing things with words," and Judith Butler's (1997) articulation of performativity in her examination of the naturalization of heteronormative gender constructions by means of their reiterative enactment (p. 44). Yet in spite of her focus on the materialization of gender through embodied performativity, Butler fails to address the material dimension of vocality, a form of "phonophobia" that Annette Schlichter (2011) associates with the repression of orality underscoring Derrida's reduction of vocal utterances to the linguistic/discursive functions of speech and the visual/spatial dimensions of writing. Schlichter argues that Butler's Derridean understanding of "materiality as textuality" privileges the intelligible through the visible because gender citationality is conceived as a series of "visible-as-legible effects" produced by the repetition of bodily acts, a form of "logocentric videocentrism" crucially depending on legibility 
(pp. 37-42). I would further suggest that by granting sight pre-eminence over sound and correlating the visual with discursive language, these influential theorists seek to literatize embodiment, whose physical manifestations are observed and analyzed through a visualist and scriptocentric theoretical lens that disregards and potentially disavows the sensorially experienced, non-visual materiality of sonic/aural/phonic/vocal performativity.

It is partly in response to the limits of "normalizing discursive-material structures" that the theorists of new materialism have developed "a posthuman approach to the subject, agency, materiality, and affect" that supports forms of creation and experimentation "grounded in the ethical imperative to rethink relations of being" (St. Pierre, Jackson and Mazzei, 2016, pp.104, 106, 108). Relying on a Deleuzian antidote to the Cartesian cogito that separates existence "into the knower and the known for the sake of knowledge" (p. 102), the discourse of new materialism proposes to lay out "a different image of thought" which is described as "a flat plane with no depth, with no hierarchies of subject/object or real/language/representation" (pp. 102, 103, 107). Acknowledging that "the dimensions of the plane of thought being laid out is not clear, nor will it ever be because it is always being laid out, becoming" (p. 103, italics in original), the proponents of this approach point to experiments conducted by "scientists, musicians, filmmakers, philosophers, artists, writers, architects," and specify that the experimental creativity they invoke might entail "putting words together differently" (p. 104). This elusively tantalizing discourse nevertheless continues to privilege ocularcentric and text-based ontological understandings of thought, matter, and the nature of being, thus raising the question of what happens to voice when examined through the lens of new materialism. In "Voice Without a Subject," Lisa A. Mazzei reconfigures voice as process and duration to foreground what she identifies as an ontological voice that "produces being in its becoming," a bold theoretical move 
enabling new materialism to free voice from the burden of signification and subjectification imposed by the humanist conception of voice "bound to $a$ specific body" where the individual is “the source of voice, agency, being," (pp. 153, 154). From a Deleuzian perspective, this ontological voice is conceived "as a surface or plane, not of $a$ subject or $a$ time," so that it becomes possible for Mazzei to argue that "thinking voice without its genesis in an organized body offers a meeting place between language and the world (pp. 154-155, italics in original). Accordingly, if voice, associated once again with discursive language defined here as "becoming-voice in lines of articulation" (p. 160), is no longer linked to a (humanist) subject of enunciation assumed to be its source, then the literary utterance must be "the product of a collective assemblage of enunciation" (p. 158), which takes us back to Bakhtin. While this conception of voice without a subject raises important questions about what constitutes agency, it does not account for the non-discursive materiality of voicing, whose performative power Mazzei brushes against in her writing when she refers to the "jolts" of utterances that "shock and surprise" because they have the capacity to affect (p. 159).

Featured in an older version of materialism, this undecipherable yet tangibly efficacious power is manifest in Louis Althusser's (1971) notion of interpellation operating as a performative utterance through which the vocal action of "hailing" simultaneously asserts the authority of the policeman's voice and positions the individual being hailed as a subject of that authority. In her analysis of hailing, Weidman argues that voice constitutes the implicit yet under-theorized element of interpellation, because "the force of the voice comes not only - as Althusser implied - from its power to name, but also, and perhaps more often, from its sonorous, material, and affective qualities (Kunreuther 2014)” (p. 46). She concludes her article by challenging anthropologists to critically examine how neoliberal corporate discourse on 
"creativity, entrepreneurship, and self-management" has productively harnessed notions of "interiority, will, and intention, associated with classic formations of the liberal subject" to reframe and repackage the modernist conception of voice as "choice, personality, uniqueness, freedom, and communication" (p. 46).

\section{Part II: Probing the Origins of Devocalization through a Performative Ethnographic Encounter with Plato's Ion}

The under-theorized aspect of voicing identified by Weidman in reference to Althusser is pivotal to Konstantinos Thomaidis's (2014) analysis of Italian cultural theorist Adriana Cavarero's (2005) critical engagement with "the historical processes whereby Western philosophy has developed its core strategies and principles of logos at the expense of the lived materiality of the voice," resulting in what she names "the devocalization of logos" (Thomaidis, 2014, pp. 77-78). Thomaidis states that these strategies and principles led to "the systematic exclusion, marginalization or silencing of the experienced, contingent and intersubjective voice, of phone, in the realm of philosophical inquiry" (p. 77). He proposes to build on Cavarero's "positioning of voice against (traditional, patriarchal and Eurocentric) understandings of logos as reason and of logos as language" to raise pertinent questions about vocality, vocal training, and singing, which he suggests "can only be explored fully in practice" (p. 78). As underlined by Thomaidis, Cavarero's critique of the primacy of sight over other senses in Western philosophy has precedents, for example in “John Dewey's condemnation of a 'spectator theory of knowledge' (Quinton 1977: 3)" whose influence on Western knowledge systems can be traced to Plato (p. 78). Thomaidis relies on etymological evidence in his investigation of "the construction of logosas-reason on the rudiments of the metaphor of sight" and foregrounds the interrelation of the 
following key terms: "idea (from the Greek idein, meaning to see and to know), theory (from the Greek theorein, meaning to see carefully and to contemplate) or science (from the Latin scientia, meaning to perceive through looking and to comprehend)" (p. 79). The assumption that "reasoning, and by extension scientific research, involves observing from a distance, clarifying through examination or relating to the sphere of ideas" (p. 79) has exerted a seemingly irrepressible influence upon the epistemological and methodological orientations of quantitative research, which has in turn positioned qualitative inquiry as 'soft' research lacking rigor, reliability, and credibility because of the reflexive, intersubjective, and dialogical processes privileged by scholar-activists engaged in feminist, anti-oppressive, decolonial, communitydriven, and arts-based research.

Following Thomaidis's prompt, I propose to momentarily return to the source of the devocalization of logos historicized by Cavarero and its ensuing proliferation of problematic "ideologies of voice" scrutinized by Weidman. This performative ethnographic fieldwork will entail an imaginary visit to ancient Greece to critically examine Plato's anxiety about performance and its implications for performance studies scholars committed to engaging with vocality. It will be crucial to keep in mind throughout this potentially perilous expedition that music, singing, and poetry are interconnected in ancient Greek culture: the lyre is an instrument that has "very ancient associations with the singing or chanting of epic poetry," and legendary lyre musicians are envisioned as powerful performers, such as "Orpheus, who could charm wild beasts with his song" (Sacks, 1995, p.147). Cavarero (2005) specifies that "in Homeric Greek, the poet is a singer [aoidos] whose song [aoide] is his voice [aude]" (p. 88). Moreover, although in ancient Greece the rhapsode performs poetry without musical accompaniment, "his manner of delivery is better described as 'chanting' rather than simply reciting, [as] in Plato's dialogue the 
Ion (named after the rhapsode Ion)" (Thomas, 1992, p. 118). An awareness of this culturallyspecific form of vocal practice will provide the necessary context for our ethnographic encounter with Plato's Ion, a text raising questions that have been foundational to the development of philosophical discourse on the arts in Western culture:

But the fact is, Ion, $[\ldots]$ you only cheat me, and you are so far from exhibiting the art of which you are a master, that you will not, even after my repeated entreaties, explain to me the nature of it. You literally assume as many shapes as Proteus, twisting and turning up and down [...] But if, as I believe, you have no art, but speak all these beautiful words about Homer unconsciously under his inspiring influence, then I acquit you of dishonesty, and shall only say that you are inspired. Which do you prefer to be thought, dishonest or inspired? (Plato, 2000a, pp. 23-24)

Plato's ambivalent relationship to performance is perhaps most palpable in this dialogue probably written several years prior to the Republic (Plato 2000b) and already underscored by a deep concern for the subversive potential of the performer's embodied agency expressed through Socrates's anxious evocation of Proteus, a sagacious and elusive shape-shifting sea-god who could foretell the future but would only do so if captured. In this text, Socrates questions the expertise of Ion, a well-known champion of rhapsodic contests. In the course of the conversation, which seems more like an interrogation, Socrates presses Ion to reveal to him the nature of his technê, yet the rhapsodist appears unable or perhaps unwilling to do so. Socrates attempts to prove to Ion that his actions on stage occur spontaneously, in spite of his own will, and argues that Ion's irrational behavior, including his unwarranted emotional reactions to the fictitious 
events depicted in Homeric epic poetry, demonstrates that rhapsodes are simply not in their right minds when performing.

The fact that there appears to be no technique involved in the art of rhapsody, no specific practical knowledge or artisanal know-how, pleases Socrates. Indeed, he states that had Ion's actions on stage been deliberately crafted by means of a technê in order to affect the audience, his behavior would have been premeditated and manipulative, so that his technê could only be equated with the art of manufacturing deception. If, on the other hand - and this is Socrates's thesis - Ion's success as a rhapsodist depends entirely on his being inspired or "possessed" by a god, who initially inspired Homer to compose his epic poetry, then it is that divinity, and not the performer, who acts on stage for the benefit of the audience. Accordingly, the authenticity of Ion's performance necessarily derives from a yielding to divine influence through a temporary loss of consciousness and relinquishing of agency.

In spite of the dialogical appearance of this scene, Socrates can't possibly lose Plato's staged debate, and in the end Ion replies to Socrates's rhetorical question "Are you inspired or dishonest?" by asserting his moral integrity over his creative agency. However, there is a serious flaw in Socrates's seemingly virtuoso performance. Towards the last third of the dialogue, having foregrounded Ion's emotional involvement in the poetry he performs on stage, Socrates asks him: “And are you aware that you produce similar effects on most of the spectators?" Ion earnestly replies

Only too well; for I look down upon them from the stage, and behold the various emotions of pity, wonder, terror, stamped on their faces when I am speaking. You see, I have to pay close attention to them, since if I make them cry I will myself be laughing when I get the 
prize money, and if I make them laugh I will myself be crying when I don't. (Plato, 2000a, p. 14)

This is an intriguing slippage in Plato's text, for if, as Ion testifies, rhapsodists are acutely aware of the reactions of the spectators upon which they gauge their success - and Socrates specifies that more than twenty thousand people attend rhapsodic contests - then the theory according to which performing implies a loss of consciousness and agency no longer holds. Of course, acknowledging that in ancient Greece a rhapsodist's technê entailed chanting the words of epic poets such as Homer rather than simply reciting them would further complicate the issue of agency since the sonic, material, and affective qualities of vocality would have to be taken into consideration.

From a performance practitioner's perspective, being moved, moving others, and being aware of this relational process is not a contradiction in terms but an experiential reality that should free Ion from the double-bind set up by Socrates like a trap. To evacuate the possibility that Ion's creative agency may hinge upon his technê, Socrates must move swiftly by proceeding with his definition of "possession” qua divine inspiration regardless of Ion's lived experience, thereby entirely dismissing the rhapsodist's testimony that it is his craft that helps him to win the contest. This enduring view of performance/possession can be traced in Western ethnographic discourses that literatize the Other by reading possession through the lens of pathology and psychoanalysis, as in the writings of Pierre Janet (1894), Jean-Claude Dorsainvil (1931), and Georges Lapassade (1997) where trance and spirit possession are diagnosed as mental illness, or through the lens of theatricality and the anti-theatrical prejudice inherited from Plato, where these ritual practices become associated with simulation by Melvile J. Herskovits (1937/1964, 1941/1990), with acting-as-pretending by Alfred Métraux (1955, 1958), as well as with intemperance, 
exhibitionism, and even deceit by Michel Leiris (1958). In his ethnography of $z \bar{a} r$ possession practices in Ethiopia, Leiris admits that his frustrated attempts at assessing the "authenticity" of ritual performance are premised upon a very elusive distinction between sincerity and simulation, leading him to conclude that, whereas the magical power of possession may perhaps once have been known to Europeans - as reflected in his final chapter which opens with a quote by Jules Michelet about the practice of sorcery during the Middle Ages in France - spirit possession, along with theatre, has become a "lie" in which Europeans can no longer believe. In her critical analysis of Western constructions of 'authentic' possession as necessarily antithetical to agency, Kalpana Ram (2013) articulates a particular type of agency that she argues is specific to mediumship because it entails developing "skilled forms of attunement" hinging upon what she describes as "fresh performativity," thereby foregrounding a more nuanced interpretation of possession that acknowledges and values "the agency of skilled performance" (Ram, 2013, p. 155). She refers to “Merleau-Ponty's (1986, pp. 145-146) description of skilled musicianship" as a form of mediumship requiring the acquisition of embodied technical competence gained through training that becomes second nature when the musician reaches the point "where conscious deliberation is left behind," a fundamental aspect of artistic mastery, for "the less a conscious subjectivity intrudes, [...] the more directly the musician is able to become a conduit for the music itself to come alive" (pp. 155-156). Ram contends that the ability to submit or yield to the life of the music is linked to a non-willful creative agency patiently cultivated through practice over time, an artisanal honing of technê that must have also applied to the vocal music performed by rhapsodists, but that Plato deliberately denigrates in the Ion.

The epistemic violence of this rhetorical erasure is strategically deployed by "the metaphysical machine [to] neutraliz[e] the power of the voice [ . . .] for millenia" (Cavarero, 
2012, p. 531), a fraught philosophical legacy compelling Thomaidis to urge performance studies scholars to "reclaim some breathing space for the contingency, temporality, presence, vulnerability and relationality of the lived voice" (p. 84). Plato's secret motivation for writing the Ion might well have been to discredit, disparage, and disown these properties of vocality, whose "sonorous materiality" (Cavarero, 2012, p. 520) he must have associated with the power of orality and the dangers of live performance, as suggested by Walter Ong (1982/2002):

Plato's entire epistemology was unwittingly a programmed rejection of the old oral, mobile, warm, personally interactive lifeworld of oral culture (represented by the poets, whom he would not allow in his Republic). The term idea, form, is visually based, coming from the same root as the Latin video, to see, and such English derivatives as vision, visible, or videotape. Platonic form was form conceived of by analogy with visible form. The Platonic ideas are voiceless, immobile, devoid of all warmth, not interactive but isolated, not part of the human lifeworld at all but utterly above and beyond it. (p. 79)

Plato's prejudice against oral culture might therefore be linked to its performativity, which cannot easily be reduced to mimesis, that is to say, the passive imitation of the world of appearances produced by holding a mirror up to nature, as discussed by Socrates and Glaucon in the opening dialogue of Book X of the Republic (for detailed critical analyses of this fragment see Diamond, 1997, and Lacoue-Labarthe, 1989). The concept of mimesis, which lies at the core of Western discourses on theatre, hinges upon an age-old dialectic between living and acting, reality and illusion, materiality and representation, authenticity and surrogacy. It is connected to the notions of objectivity and subjectivity, the perception and acknowledgement of difference, as well as seemingly irreducible binary oppositions such as mind versus body, spirit versus matter, 
the abstract versus the concrete, signifier versus signified, and so forth. Such pervasive dichotomies fail to account, however, for the non-discursive performativity of vocality, whose subjunctive mood and liminality (see Turner, 1986, 1966/1995) elude visualist conceptions of mimesis. For Conquergood, who argues that "performance studies scholars must continue to engage with the visualist/textualist bias of western intellectual systems" (2013a, p. 48), the semantic genealogy of the term performance consists in a movement from mimesis as imitation, to poiesis as construction, to kinesis as dynamism and transformation. Conquergood highlights the passage from poiesis, defined by Turner (1982) as "making, not faking," to kinesis, which he links to postcolonial theorist Homi Bhabha's (1994) "urgent political view of performance as breaking and remaking," and interprets this crucial transition as "a move from cultural invention to intervention" (2013a, p. 56) which foregrounds creative agency.

Whereas performance has been productively reclaimed by qualitative inquiry, the notion of objectivity, whose scientific aura continues to legitimize quantitative approaches to research, remains rooted in a deep-seated faith, nowadays mostly devoid of any specific religious foundation, that human intellectual powers of rational understanding can provide reliable answers about the riddle of human existence. This discursive quest for certainty can be traced to Plato's decision to draw the line, as it were, between enlightenment and self-delusion. In The Taste of Ethnographic Things, Paul Stoller (1989) reflects on the impact of Plato's legacy on Western knowledge systems:

Plato's quest for Truth (or Forms) through objectivity was his solution to the puzzle of the infinite variability to be found in the world of appearances. And so, Plato becomes the first thinker to distinguish appearance from reality. Behind every appearance, he tells us, there is a hidden immutable Form. [. . .] The birth of 
metaphysics, of Ultimate Forms, of the search for Truth, set the boundaries between art and metaphysics. Plato wanted the dramatic artists expelled from his Republic, for the sentiments that dramatists are capable of provoking lead people back to the heroic myths and ignorance, rather than toward the discovery of Ultimate Forms. [...A]rt and metaphysics become mutually exclusive [. . .]. These metaphysical distinctions have not been disputed; rather, thinkers since Plato have disputed the question of how we discover reality (the One) hidden behind the appearances (the Many), how we arrive at Truth. [T] he search for the One in the Many has [therefore] been at the heart of Western scholarly discourse. (pp. 48-49, 138)

Metaphysics can be defined as the study of the philosophical problems that can only be apprehended outside the realm of human sensory experience. According to metaphysics, embodied experience obscures, veils or dissimulates the answers to such problems. Although from Plato to Descartes, the senses are not to be trusted, sight is exceptionally privileged by metaphysics, for it mediates appearances to the mind, which is thereby able to scrutinize the Many in the search for the One. Modernity is founded upon the objective gaze of the philosopher, the scientist, the ethnographer, piercing through the material world of appearances in order to dis-cover that which lies beyond it and remains invisible to the untrained eye.

In his discussion of the legacy of mimesis in contemporary French theory, namely, poststructuralism and deconstruction, Mihai Spariosu (1984) maps out a continuity between modernism and postmodernism through the concept of truth as revelation which he associates with what he names "truth-science," a pervasively dominant approach that he links to Plato's perspective. He provocatively argues that even post-structuralism and deconstruction are unable to renounce "the power-principle which lies at the foundation of Western civilization" because 
the efficacy of Western theoretical discourses crucially depends upon such power, which they perpetuate through the use of discursive language (pp. 63, 67, 77). This critique applies to theories of embodiment that remain indebted to linguistic models of analysis hinging upon the power of discursive reason. As stressed by Stoller (1997) in Sensuous Scholarship, languagebased theories become unproductive when applied to the embodied dimensions of performance. He asserts that "even the most insightful writers consider the body as a text that can be read and analyzed," and points out that the discursive practices of postmodern theorists privilege a language that is "bloodless" and curiously disembodied, thereby reinforcing "the very principle they critique - the separation of mind and body, which [...] regulates and subjugates the very bodies they would liberate" (iii-xv). Given that embodiment and vocality are central to performance practice, performance studies scholars must pay particular attention to the language available to them in their theoretical toolkit and to the mechanisms of philosophical strategies that are complicit with the "systematic exclusion, marginalization or silencing" of the lived voice (Thomaidis, 2014, p. 77), and that continue to promote a disembodied and devocalized economy of knowledge. It is within the purview of performance studies to confront the limitations of such regimes of knowledge by engaging with historically and culturally specific discourses on vocality invested in the regulation, subjugation or eradication of dialogism, heteroglossia, and polyphony (Bakhtin, 1981).

Ironically, Plato, and later Descartes, practiced metaphysics through story-telling and dramatization to turn the unveiling of Truth into a spectacular form of revelation. Plato thus contrived the allegory of the cave by resorting to the theatrical technique of shadow-puppets to convey the distinction between optical illusion and philosophical insight. In his Méditations métaphysiques (1641/2009), Descartes also made up fantastical stories, such as the one where he 
sits in his house, peering through the window frame at an ordinary street scene featuring fleeting passers-by - but what if, he suddenly asks, abruptly interrupting the flow of the story, I was deceived by some mauvais génie who conjures up ghosts or winds up mechanical men costumed with hats and coats that he sends parading down the street? Significantly, sound and vocality are muted by Plato and Descartes's silent stories about sight.

Given Descartes's Platonic obsession with optical illusion, it is no wonder that his Dioptrique (in Discours de la méthode 1637/2000) is filled with hand-drawn sketches of human eye-balls, illustrations of the ways in which light is refracted by the retina, perspectives and vanishing points, anatomical drawings documenting how the eyes are connected to the brain via the optical nerves, or how the colors of the rainbow become perceptible to human eyesight, along with notions of astronomy and detailed instructions about the proper way of crafting eye-glasses. Descartes's preoccupation with sight is largely responsible for the visualist logic of Western scientific discourse, for the French philosopher has been upheld as one of the founding fathers of modern science, along with Galileo whose telescope is believed to have inspired Descartes's anticipation of the invention of the microscope. Stephen Gaukroger (2017) hence argues that Descartes's "optical instrument model of cognition" gave rise to the notion that we see representations which are in the mind rather than in the world, a representationalism that creates "separate internal and external worlds" by offering an account of vision from which derive "many of the problems that have been associated with the metaphysical doctrine of mind-body dualism" (p. 124).

While in Descartes's fantasy of the mauvais génie the voice of this mysterious supernatural creature is never heard, in Plato's imaginary dialogues, the aural nature of vocality that endows Ion's chanting with non-discursive performative power is never acknowledged, nor is Glaucon's 
incapacity to represent sound visually when holding up a mirror to nature. Yet I would argue that voicing is central to Plato's dramatization of philosophy, for, as Jean Nienkamp (1999) remarks, "Plato did not write systematic philosophical treatises, but dramatic philosophical dialogues in which he was not himself a speaker" (p. 2). Indeed, if we follow Socrates's definition of the three types of storytelling outlined in Book III of the Republic, Plato's writings necessarily fall under the category of imitation since they stage dialogues involving various characters while the author remains outside the dramatic frame. In this section of the Republic, Socrates clearly condemns imitative storytelling by providing the example of Homer, whom he accuses of attempting to suggest that someone other than himself is speaking, as if he were "possessed" by the spirit of his own characters. However, the Socrates who indicts Homer in the Republic is himself a fictional character created by Plato. Writing in the voice of his mentor, Plato fashions an imitation of the historical figure of Socrates whom he casts in the role of the main protagonist in his dramatic dialogues as if attempting to summon the master-philosopher back to life. Even though Plato devises such séances for "honest" pedagogical purposes, he nevertheless resorts to ventriloquism and puppetry as he hovers invisibly above his craftily staged dramas. Ironically, had his ideal republic existed, Plato would have most likely been sentenced to exile along with Homer, Ion, and all the other unwanted artists.

What is perhaps most perplexing about Plato's anxiety vis-a-vis performance is that embodiment and vocality must have played a pivotal role in the traditional pedagogy of ancient Greece, where philosophy was an interactive public forum, or a sport event of the mind that probably took the form of improvised arguments between highly skilled debaters. Within this culturally specific context, the historical Socrates must have had to perfect the type of performative technê that Ion is denied by Plato's "Socrates," for the vocalization of logos must 
have required Greek philosophers to strike a balance between discursive logic and intuition, rationality and emotion, as well as verbal and non-verbal communication, and Socrates must have mastered these techniques brilliantly. Whereas in his own lifetime Socrates's popularity might have been ascribed in part to his being inspired or "possessed" by his love for truth, the skills that he acquired through embodied practice must have been critical to his success as a public orator. Moreover, Socrates must have excelled at dialogism, since an overly didactic and coercive approach might have produced resistance instead of the "emotional and behavioral sympathy" which Ruby Blondell (2002) argues was pivotal to Athenian pedagogy, and which most likely depended on a "condensation of experience and practice" produced by a pleasurable dialogical process, a live debate whose ultimate outcome was probably assumed to be unpredictable (Blondell, 2002, p. 81).

In Plato's written dialogues, conversely, the authority of "Socrates" can only prevail if the responses provided by his interlocutors help Plato to develop the overall argument he intends to present to the reader. This is especially clear in the Ion, a dialogue in which the respondent's perspective is systematically dismissed as self-contradictory thus illogical, so that Ion's agency and honesty necessarily cancel each other out while Plato's own positionality remains beyond scrutiny. This theatrical stratagem seeking to prove that honest rhapsodists have no artistic mastery may be envisioned as a kind of "primal scene" whereby the unsuspecting spectator becomes witness to the disturbing origins of the devocalization of logos, whose epistemic violence is directed against Ion, an acclaimed epic story-teller and established vocal expert. Revisiting this scene through imaginative ethnography helps to highlight its (ironic) performative dimension: emboldened by the power of the metaphysical machine evoked by Cavarero, Plato 
unscrupulously appropriates the "voice" of his mentor Socrates to silence Ion and cleanse logos from vocality for the rest of time - or so he hopes.

As specified by Cavarero, the Platonic devocalization of logos reduces "the phone to the acoustic sign of the idea," a conceptual operation which entails silencing the phonic/sonic properties of vocality and theorizing the latter as "the general voice of language, subsumed under a videocentric logic of the signified and controlled by the system of signification," a linguistic economy of knowledge which assigns spoken speech itself to "the register of signs generated by writing" Cavarero, 2005, p. 83) and which, as I argued in Part I, leads to scriptocentrism. Cavarero infers from Plato's "obsessive attack on the rhapsodic voice" that his determination to sever logos from its sonorous sense stems from his fear of "the corporeal realm of the vocal" (Cavarero, 2005, p. 84), that is to say, the immemorial embodied dimension of vocality that connects phone to what Ong describes as the "mobile, warm, personally interactive lifeworld of oral culture" (Ong, 1982/2002, p. 79) and that Cavarero associates with "the voice of acoustic pleasure, the voice that is rhythm and breath, the voice that escapes the control of the videocentric system of language" (Cavarero, 2005, p. 84). What the metaphysical machine cannot reduce to a concept, an abstraction or a metaphor, then, is the distinctively unique sonority of Ion's voice, whose secret escapes Plato's grasp as it bounces off the tight boundaries of discursivity, propelled into posterity by the power of vibration and resonance.

AS this imaginary visit to ancient Greece comes to an end and the ethnographer prepares to return to the proverbial safety of the ivory tower, a fortuitous meeting occurs with interdisciplinary voice studies scholar Konstantinos Thomaidis, who also happens to be working in this historical geolocation for his new project. ${ }^{1}$ Thomaidis generously shares reflections based on his current research and describes Socrates's symposium sonic environment as inherently 
dialogic, where interlocutors are continuously engaged in the process of speaking/listening and listening/speaking, irrevocably implying the other and invoking their response. He stresses that this phonic exchange is the first and foremost structural tenet of the symposium's particular vocal acoustics: there are no outside listeners but only listener/speakers and speaker/listeners (with the exception, perhaps, of the "overhearing" researcher conducting imaginative fieldwork), and the length of their sentences or spoken passages, alongside other extra-linguistic and pragmatic features, provide important clues about the vocally embodied rhythm of interlocution. Moreover, Thomaidis specifies that the symposium environment is inclusive of music, another element that must be taken into account when attempting to re-imagine its sonic dimension, yet in his written dialogues Plato expresses a distrust of musicality and rhythm, which are, of course, central to orality, because he suspects that the aural/phonic qualities of logos might distract listeners/speakers from the primacy of discursive meaning, as in the case of epic poetry chanted by skillful rhapsodists.

Although Plato salvages a rhetorical victory for Socrates in the Ion, he manages to do so only by strategically overlooking the complex question of creative agency. Plato's dramatization of philosophy through the staging of dialogues is jeopardized by his efforts to contain the dangers of performativity, thereby revealing that the effects of mimetic pedagogy might be much more difficult to control than the philosopher-dramatist envisioned. His failed attempt to revive in his writing the voice of a master of the oral tradition epitomizes this conundrum: Platonic dialogues, because they feature a character who is almost-Socrates-but-not-quite, constantly refer us back to the man who once initiated Plato to the art of philosophical inquiry. This elusive signified remains outside the scope of the metaphysical theatron, as if a shade trailing behind the stage director, peering at the script over Plato's shoulder and amusedly gauging the verisimilitude of 
the lines attributed to its illustrious double, whose "renown has echoed down the centuries, allowing Socrates to exert an unparalleled influence on the European tradition of philosophy and literature" (Blondell, 2002, p.85). For, irrespective of the director's intentions, the final coup de théâtre lies in the spectacular metamorphosis of the allegedly heretic gadfly of Athens into a legendary philosopher-hero of Homeric proportions.

\section{Conclusion}

"What non-literal forms of ethnographic representation might a contemporary, critical, and historically informed ethnographic project take? How can we move beyond writing culture?” (Harrison, 2014, p. 245). Resisting the ethnographic project of "literatizing non-literate societies" could be one way of responding to the questions raised by Harrison about the limitations of ethnographic writing, and this might be achieved by envisioning an alternative to the type of agency associated with modernist, liberal, and neoliberal conceptions of self, free-will, and individualism. This might entail experiencing vocality as a vital source of embodied knowledge and creative energy connected to the vibrancy of intangible cultural heritage that is remembered, reactivated, and reclaimed through story and song:

The oral epic (and by hypothetical extension other forms of narrative in oral cultures) has nothing to do with creative imagination in the modern sense of this term, as applied to written composition. [.. .] When a bard adds new material, he processes it in the traditional way. [...] 'Song is the remembrance of songs sung' (Peabody, 1975, p. 216). [. . .]

Basically, the singer is remembering in a curiously public way - remembering not a memorized text, for there is no such thing, nor any verbatim succession of words, but the themes and formulas that he has heard other singers sing. [. . .] The oral song (or other 
narrative) is the result of interaction between the singer, the present audience, and the singer's memories of songs sung. In working with this interaction, the bard is original and creative on rather different grounds from those of the writer. (Ong, 1982/2002, pp. 143-

Fully embodying this alternative agency might require being open to learning from Homer's intimate relationship with the sonorous materiality and phonic substance of vocality, and from his finely tuned sensitivity to its ephemeral performative power:

The spoken word is always an event, a movement in time, completely lacking in the thinglike repose of the written or printed word. Our complacency in thinking of words as signs is due to the tendency [. . .] to reduce all sensation and indeed all human experience to visual analogues. [. . . ] Oral man is not so likely to think of words as 'signs', quiescent visual phenomena. Homer refers to them with the standard epithet 'winged words' — which suggests evanescence, power, and freedom: words are constantly moving, but by flight, which is a powerful form of movement, and one lifting the flier free of the ordinary, gross, heavy, 'objective' world. (Ong, 1982/2002, pp. 73-75)

A more politically urgent engagement with vocality, which might produce a deeper transformation and spiritual awakening, could take the form of a patient and humble apprenticeship that would entail learning how to listen to (and perhaps sing with?) the Elders and Traditional Knowledge Keepers who belong to contemporary oral cultures whose continuity critically hinges upon the vulnerability, relationality, and reciprocity of the lived voice:

ME: Why do I use a drum?

OLD WOMAN: To touch the earth.

ME: Then why do I sing with it?

OLD WOMAN: To allow the earth to touch you.

ME: What am I singing for? 
OLD WOMAN: So that someday you might sing the one note that joins your heartbeat and the earth's heartbeat to the heartbeat of everything.

ME: You're saying that drumming and singing, anything that leads me inward and then outward, are just like praying and meditating.

OLD WOMAN: You are getting wiser, my boy.

$* * *$

ME: What is the point of prayer and meditation?

OLD WOMAN: To bring you closer to the Great Mystery.

ME: So I can understand it?

OLD WOMAN: No. So you can participate in it.

$* * *$

I grew up spiritually after that.

(Wagamese, 2016, pp. 75, 93) 


\section{References}

Alsup, J. (2004). Protean subjectivities: Qualitative research and the inclusion of the personal. In S. G. Brown \& S. I. Dobrin (Eds.), Ethnography unbound: From theory shock to critical praxis (pp. 219-237). Albany, NY: State University of New York Press.

Althusser L. (1971). Ideology and ideological state apparatuses. In Lenin and Philosophy and Other Essays (pp. 121-76). New York: Monthly Review Press.

Austin J. L. (1962). How to do things with words. Oxford, UK: Clarendon.

Bailleux, B. (2001). Et dedans Et dehors. . .la voix. Étude comparée du jeu transitionnel du travail de la voix dans la construction de l'identité de comédiens et de psychothérapeutes [Inside and outside ... the voice. Comparative study of the transitional role played by vocal work in identity construction for actors and psychotherapists] (Doctoral Dissertation). Université Catholique de Louvain. Louvain-la-Neuve: Presses universitaires de Louvain.

Bakhtin M. M. (1981). The dialogic imagination: Four essays. Austin: University of Texas Press.

Bhabha, H. (1994). The Location of Culture. London: Routledge.

Blondell, R. (2002). The play of character in Plato's dialogues. New York: Cambridge University Press.

Bourdieu, P. (1980). Le Sens pratique [The Logic of practice]. Paris: Les Éditions de Minuit. Bourdieu, P. (2001). Langage et pouvoir symbolique [Language and symbolic power]. Paris: Seuil.

Butler J. (1997). Excitable speech: A politics of the performative. New York: Routledge. 
Cavarero A. (2005). For more than one voice: Toward a philosophy of vocal expression. Stanford, CA: Stanford University Press.

Cavarero A. (2012). Multiple voices. In Stern, J. (Ed.), The sound studies reader (pp. 520-532). New York: Routledge.

Clifford, J., \& Marcus, G. E. (Eds). (1986). Writing culture: The poetics and politics of ethnography. Berkeley: University of California Press.

Conquergood, D. (2013a). Beyond text: Towards a performative cultural politics. In Johnson P. (Ed.), Cultural struggles: Performance, ethnography, praxis (pp. 47-63). Ann Arbor: University of Michigan Press.

Conquergood, D. (2013b). Performance studies: Interventions and radical research. In Johnson P. (Ed.), Cultural struggles: Performance, ethnography, praxis (pp. 32-46). Ann Arbor: University of Michigan Press.

Conquergood, D. (2013c). Re-thinking ethnography: Towards a critical cultural politics. In Johnson P. (Ed.), Cultural struggles: Performance, ethnography, praxis (pp. 81-103). Ann Arbor: University of Michigan Press.

de Saussure F. (1988). Course in General Linguistics (1921). Chicago: Open Court.

Descartes, R. (2000). Discours de la méthode [Discourse on the method]. Paris: GarnierFlammarion. (Original work published 1637)

Descartes, R. (2009). Méditations métaphysiques [Meditations on first philosophy]. Paris: Garnier-Flammarion. (Original work published 1641)

Diamond, E. (1997). Unmaking mimesis. New York: Routledge.

Dorsainvil, J. C. (1931). Vodou et névrose. Port-au-Prince, Haïti: La Presse. 
Ellis, C. (2004). The ethnographic I: A methodological novel about autoethnography. Walnut Creek, CA: AltaMira Press.

Emerson, R. M., Fretz, R. I. \& Shaw, L. L. (1995). Writing ethnographic fieldnotes. Chicago: University of Chicago Press.

Gaukroger, S. (2017). Cartesianism and visual cognition: The problem with the optical instrument model. In S. Gaukroger \& C. Wilson (Eds.), Descartes and Cartesianism: Essays in honour of Desmond Clarke (pp. 112-124). Oxford: Oxford University Press.

Harrison, A. K. (2014). Ethnography. In Patricia Leavy (Ed), Oxford handbook of qualitative Research (pp.223-253). Oxford: Oxford University Press.

Herskovits, M. J. (1964). Life in a Haitian valley (1937). New York: Octagon.

Herskovits, M. J. (1990). The Myth of the Negro past (1941). Boston: Beacon.

Janet, P. (1894). Névroses et idées fixes. Études expérimentales sur les troubles de la volonté, de l'attention, de la mémoire, sur les émotions, les idées obsédantes et leur traitement [Neuroses and obsessions. Experimental study on the disorders of the will, attention, and memory, as well as on emotions and compulsory obsessions, and their treatment]. Paris: Félix Alcan.

Jones, S. H. (2008). Autoethnography: Making the personal political. In N. K. Denzin \& Y. S. Lincoln (Eds.), Collecting and interpreting qualitative materials (3rd ed.) (pp.205-245). Los Angeles: Sage.

Karpf, A. (2006). The Human Voice: The Story of a Remarkable Talent. London: Bloomsbury.

Kemmis, S. \& McTaggart. R. (2000). Participatory action research. In N. K. Denzin \& Y. S. Lincoln (Eds.), Handbook of qualitative research (2nd ed.) (pp. 567-605). Thousand Oaks, CA: Sage. 
Kunreuther L. (2014). Voicing subjects: Public intimacy and mediation in Kathmandu. Berkeley: University of California Press.

Lacoue-Labarthe, P. (1989). Typography: Mimesis, philosophy, politics. Cambridge: Harvard University Press.

Lapassade, G. (1997). Rites de possession [Spirit possession rituals]. Paris: Anthropos.

Lassiter, L. E. (2005). The Chicago guide to collaborative ethnography. Chicago: University of Chicago Press.

Leavy, P. (2009). Method meets art: Arts-based research practice. New York: The Guilford Press.

Leiris, M. (1958). La possession et ses aspects théâtraux chez les Ethiopiens de Gondar [Spirit possession and its theatrical dimension in the Ethiopians of Gondar]. Paris: Plon.

Lincoln, Y. S., \& Denzin, N. K. (Eds). (2003). Turning points in qualitative research: Tying knots in a handkerchief. Walnut Creek: Altamira.

Magnat, V. (2017). Occitan music revitalization: From postcolonialism to Altermondialisation. Popular Music and Society 40 (1), 61-74.

Mascia-Lees, F., Sharpe, P., \& Cohen, C.B. (1989). The postmodern turn in anthropology: Cautions from a feminist perspective. Signs 15 (1), 7-33.

Mazzei, Lisa A. (2016). Voice without a subject. Cultural studies $\leftrightarrow$ Critical methodologies $16: 2,151-161$

Merleau-Ponty, M. (1986). Phenomenology of perception. London: Routledge and Kegan Paul. Métraux, A. (1955). La comédie rituelle dans la possession [Ritual comedy in spirit possession]. Diogène 11, 26-49.

Métraux, A. (1958). Le Vaudou Haïtien [Haitian Vodou]. Paris: Gallimard. 
Minks A. (2013). Voices of play: Miskitu children's speech and song on the Atlantic Coast of Nicaragua. Tucson: University of Arizona Press.

Nienkamp, J. (1999). Plato on rhetoric and language: Four key dialogues. Mahwah, NJ: Hermagoras Press.

Ong, W. J. (2002). Orality and literacy: The technologizing of the world (1982). London \& New York: Routledge. (Original work published 1982)

Peabody, B. (1975). The winged word: A study in the technique of ancient Greek oral composition as seen principally through Hesiod's works and days. Albany, NY: State University of New York Press.

Pink, S. (2006). The future of visual anthropology: Engaging the senses. London: Routledge.

Pink, S. (2009). Doing sensory ethnography. London: Sage.

Plato. (2000a) The Ion. In Selected dialogues of Plato (pp. 3-24). New York: Modern Library.

Plato. (2000b) The Republic. New York: Cambridge University Press.

Quinton, A. (1977). Inquiry, thought and action: John Dewey’s theory of knowledge. In R.S. Peters (Ed.), John Dewey Reconsidered (pp. 1-17). London: Routledge.

Rabinow, P., \& Marcus, G. E., with Faubion, J. D. \& Rees, T. (2008). Designs for an anthropology of the contemporary. Durham \& London: Duke University Press.

Radcliffe-Brown, A. R. (1952). Historical note on British social anthropology. American Anthropologist 54 (2), 275-277.

Ram, K. (2013). Fertile disorder: Spirit possession and its provocation of the Modern. Honolulu: University of Hawai'i Press.

Sacks, D. (1995). A Dictionary of the ancient Greek world. New York \& Oxford: Oxford University Press. 
Schlichter, A. (2011). Does voice matter? Vocality, materiality, gender performativity. Body \& Society 17 (1), 31-52.

Schneider, S. \& Wright, C. (Eds). (2010). Between art and anthropology: Contemporary ethnographic practice. New York: Berg.

Sidtis, D. \& Kreiman, J. (2011). Foundations of Voice Studies. Hoboken. NJ: Wiley-Blackwell. Spariosu, M. (1984). Mimesis in contemporary French theory. In M. Spariosu (Ed.) Mimesis in contemporary French theory: an interdisciplinary approach (pp. 66-108). Amsterdam: John Benjamins.

Stoller, P. (1989). The taste of ethnographic things: The senses in anthropology. Philadelphia: University of Pennsylvania Press.

Stoller, P. (1997). Sensuous scholarship. Philadelphia: University of Pennsylvania Press.

St. Pierre, E. A., Jackson, A. Y., and Mazzei, Lisa A. (2016). New empiricisms and new materialisms: Conditions for new inquiry. Cultural studies $\leftrightarrow$ Critical methodologies 16:2, 99-110.

Taylor, D. (2003). The archive and the repertoire: Performing cultural memory in the Americas. Durham: Duke University Press.

Taylor, D. (2008). Performance and Intangible Cultural Heritage. In T. C. Davis (Ed), The Cambridge companion to performance studies (pp. 91-104). Cambridge and New York: Cambridge University Press.

Taylor, D. (2016). Saving the 'live’? Re-Performance and Intangible Cultural Heritage. Études Anglaises 69 (2), 149-161. 
Tedlock, B. (2000). Ethnography and ethnographic representation. In N. K. Denzin \& Y. S. Lincoln (Eds), Handbook of qualitative research (2nd ed.) (pp. 455-486). Thousand Oaks, CA: Sage.

Tenzer, M., \& Roeder, J. (Eds). 2011. Analytical and cross-cultural studies in world music. Oxford: Oxford University Press.

Thomaidis, K. (2014). The revocalization of Logos? Thinking, doing and disseminating voice. Studies in Musical Theatre 8 (1), 77-87.

Thomas, R. (1992) Literacy and orality in ancient Greece. New York: Cambridge University Press.

Turner, V. W. (1982). From ritual to theatre. New York: PAJ.

Turner, V. W. (1986). Dewey, Dilthey, and drama: An essay in the anthropology of experience. In V. W. Turner, M. Edward (Eds), The anthropology of experience (pp. 33-44). Urbana: University of Illinois Press.

Turner, V. W. (1991). Dramatic ritual/ritual drama: Performative and reflexive anthropology. In B. Marranca \& G. Dasgupta (Eds), Interculturalism and Performance: Writings from PAJ (pp. 99-111). New York: PAJ.

Turner, V. W. (1995). The ritual process: Structure and anti-structure. Piscataway, NJ: Transaction Publishers. (Original work published in 1966)

Wagamese, R. (2016) Embers: One Ojibway's meditations. Madeira Park, BC: Douglas \& McIntyre.

Weidman, A. (2014). Anthropology and voice. Annual Review of Anthropology 43: 37-51. Williams, R. (1983). Culture and Society. New York: Columbia University Press. (Original work published in 1958) 
${ }^{1}$ I am grateful for the helpful bibliographic sources and valuable research insights that Konstantinos Thomaidis generously shared with me. Dr. Thomaidis's scholarly investigation of vocality grounded in embodied knowledge has been an endless source of inspiration for my own work. 